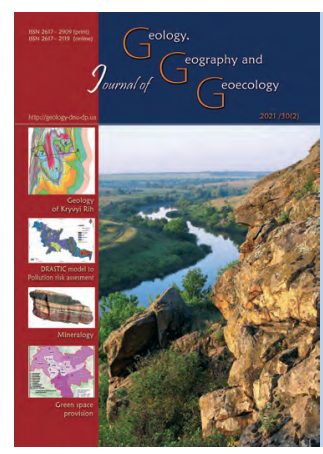

Journal of Geology.

Geography and

Geoecology

ISSN 2617-2909 (print)

ISSN 2617-2119 (online)

Journ.Geol.Geograph.

Geology,

30(2), 379-388.

Journal home page: geology-dnu.dp.ua

doi: $10.15421 / 112134$

Imrani Z. T., Veliyeva G. V.

Journ. Geol. Geograph. Geoecology, 30(2), 379-388.

\title{
Methodological basis of zoning of tourism-recreation reserves and tourism potential of Gusar region of the Republic of Azerbaijan
}

Imrani Zaur Tahir ${ }^{1}$, Veliyeva Gunel Vahid ${ }^{2}$

${ }^{1}$ Institute of Geography named after acad. H.A. Aliyev of National Academy of Sciences of Azerbaijan. Baku, Azerbaijan, zaurimrani@mail.ru

${ }^{2}$ Baku State University, Baku, Azerbaydjan

Received: 10.01 .2021

Received in revised form: 20.01 .2021

Accepted: 11.04.2021

Abstract. In modern times, the potential opportunities of the regions are studied using different methodological approaches to achieve sustainable socio-economic development, and zoning is carried out in different directions to stimulate their future activities. The zoning is based on the demand for available resources and takes into account the level of socio-economic development of the region. At present, the study of tourism in the Republic of Azerbaijan by regions is encouraging attention due to its relevance. However, research work on the identification of tourism zones in the country and the zoning of these areas is weak. From this point of view, the article studies the tourism potential of Gusar region and provides a scheme for its tourismrecreation zoning which meets present-day requirements and attracts attention due to its relevance. The article analyses the development strategy of tourism, which is a new and promising field in the Republic of Azerbaijan, identifies the main directions of this strategy, and explores ways to solve existing problems. For this purpose, first, the criteria for zoning of tourism and recreation resources were determined; then natural and anthropogenic tourism resources were assessed through the example of Gusar region; information on natural and historical-architectural monuments of interest to tourists was provided; the number of hotels operating in the region over the past five years, the number of rooms, full hotel capacity and overnight stays, as well as the income, expenses, and the difference between them were made on the basis of statistical and comparative analysis. Based on the information obtained, for the first time, a "Zoning Map of Tourism and Recreation Resources of Gusar Region" was compiled; the strengths and weaknesses of the tourism sector were identified, and future threats and opportunities for the development of this sector were analysed by means of the SWOT analysis. According to the analysis, the strengths of the region included the favourable economic and geographical position, the availability of unique natural and historical-architectural monuments, the availability of natural and ecological conditions to provide recreation for tourists, and opportunities for ecological, rural, religious, trekking, and other tourism types, etc. Weaknesses included the concentration of hotels mainly in the region's centre, insufficient promotion of tourist attractions, poor level of service and vocational training, lack of guides, etc. The opportunities were high tourism potential, organisation and development of local tourist routes, an abundance of labour resources, etc., while the threats included the aggravation of the geopolitical situation in the border areas, the intensification of natural disasters, etc.

Keywords: tourism-recreation resources, natural monuments, historical-architectural monuments, zoning, hotel

\section{Методологічні основи районування туристично-рекреаційних заповідників туристичного потенціалу Гусарського регіону Республіки Азербайджан}

\author{
Імрані Заур Тахір ${ }^{1}$, Велиєва Гунель Вахід²
}

${ }^{1}$ Інститут географії імені акад. Н.А. Алієва Національної академії наук Азербайджану, Баку, Азербайджан, zaurimrani@mail.ru

${ }^{2}$ Бакинський державний університет, Баку, Азербайджан

Анотація. У наш час потенційні можливості регіонів вивчаються з використанням різних методологічних підходів для досягнення стійкого соціально-економічного розвитку, а зонування здійснюється в різних напрямках для стимулювання їхньої подальшої діяльності. Зонування базується на попиті на наявні ресурси та враховує рівень соціально-економічного розвитку регіону. В даний час вивчення туризму в Азербайджанській Республіці за регіонами є дуже актуальним. Однак дослідницька робота з визначення туристичних зон у країні та районування цих районів $є$ недостатньою. 3 цієї точки зору у статті висвітлено результати вивчення туристичного потенціалу регіону Гусар та забезпечено його туристично-рекреаційне районування, яке 
відповідає сучасним вимогам та привертає увагу своєю актуальністю. У статті проаналізовано стратегію розвитку туризму, яка $\epsilon$ новою та перспективною сферою в Азербайджанській Республіці, визначено основні напрямки цієї стратегії та досліджено шляхи вирішення існуючих проблем. Для цього спочатку були визначені критерії зонування туристично-рекреаційних ресурсів; тоді природні та антропогенні туристичні ресурси оцінювались на прикладі регіону Гусар; була надана інформація про природні та історико-архітектурні пам’ятки, що цікавлять туристів; кількість готелів, що працювали в регіоні за останні п’ять років, кількість номерів, повну місткість готелів та ночівлі, а також доходи, витрати та різниця між ними були зроблені на основі статистичного та порівняльного аналізу. На основі отриманої інформації вперше було складено Карту зонування туристичних та рекреаційних ресурсів Гусарського краю; було визначено сильні та слабкі сторони туристичного сектору, а також за допомогою SWOT-аналізу проаналізовано майбутні загрози та можливості для розвитку цього сектору. Згідно 3 аналізом, сильні сторони регіону включали сприятливе економічне та географічне положення, наявність унікальних природних та історико-архітектурних пам'яток, наявність природних та екологічних умов для забезпечення відпочинку туристів та можливості для екологічних, сільських, релігійних, трекінг та інших видів туризму тощо. До слабких сторін належать концентрація готелів переважно в центрі регіону, недостатня підтримка туристичних визначних пам'яток, низький рівень сервісного та професійного навчання, відсутність гідів тощо, розвиток місцевих туристичних маршрутів, велика кількість трудових ресурсів тощо, тоді як загрози включали загострення геополітичної ситуації в прикордонних районах, посилення стихійних лих тощо.

Ключові слова: туристично-рекреаційні ресурси, природні пам'ятки, історико-архітектурні пам'ятки, зонування, готель

\section{Introduction}

Tourism has been one of the fastest-growing spheres of the non-oil sector in Azerbaijan in recent years. Thus, benefitting from great opportunities, tourism provides regional development based on the efficient use of local resources, provides a basis for the improvement of infrastructure, as well as serves as an additional source of income for the population. In a broader sense, tourism is a means that affects the formation of the state budget, the improvement of villages and cities, the preservation of historical and architectural monuments, and the development of small and medium enterprises (Imrani, 2018). From this point of view, the identification of ways to develop tourism in the Republic of Azerbaijan, the study of problems in this area, as well as the zoning of tourism and recreation resources on a scientific basis are of great scientific, theoretical, and practical importance.

In order to develop tourism, which is a new and promising field in the Republic of Azerbaijan, the "Law on Tourism" in 1999, the "State Program for the Development of Tourism in the Republic of Azerbaijan" in 2002-2005 and 2010-2014, the "State Program on the Development of Resorts in the Republic of Azerbaijan" in 2009-2018, the announcement of 2011 as the "Year of Tourism", the "Strategic Roadmap for the Development of the Specialised Tourism Industry in the Republic of Azerbaijan" in 2016, and other decisions were of great importance. However, despite the work done, it was not possible to fully and comprehensively solve the existing problems in the tourism sector.

In accordance with the changing dynamics of the tourism sector, five main directions in the development of tourism strategy in Azerbaijan have been identified as global trends: 1. development and promotion of the tourism brand; 2 . application of a simplified visa regime; 3. attracting large-scale investment projects; 4. creating an attractive environment for investors; and 5. strengthening international cooperation (Strategic Roadmap..., 2016).

In recent years, the share of tourism in the economy of the Republic of Azerbaijan has increased significantly. If we analyse 2010-2018, it could be seen that the share of tourism in GDP increased from $1.0 \%$ to $2.2 \%$. The reason for the increase was the announcement of 2011 as the "Year of Tourism" and the allocation of USD 828 million to the tourism industry that year (National Accounts..., 2019). As a result, the tourism sector began to develop rapidly, new hotels were built in a short time, and the number of tourists visiting the country increased 2.5 times.

\section{Generalisation of existing problems and goals}

One of the most important tasks facing each country is to increase employment and reduce unemployment by identifying ways to effectively use labour resources in solving existing socioeconomic problems. From this point of view, with the development of the tourism sector in Gusar region, it is possible to create new jobs, thereby eliminating the employment problem, at least in part. For this, first, it is necessary to study the attractive tourism-recreation potential of the region and to determine zoning criteria by conducting its economic-geographical assessment.

Tourism and recreation resources are natural, historical, cultural, and socio-economic resources that are or can be used to meet the recreational needs of society (Alexandrova, 2002). Natural-recreational resources include resources used in the process of restoration and development of human physical and mental strength, ability to work, and health. Almost all natural resources have recreational and tourism potential but the degree of their use is different. It 
depends on the demand for recreational resources and the level of specialisation in the region.

Tourist and recreation zoning - industry-specific zoning (Fedotov, 2013). Given its specialisation in specific socio-economic activities, tourist-recreation zoning refers to industry-specific zoning. It should be considered as a tool for studying the territorial organisation of tourism and as a reflection of a certain stage in the territorial development of tourism (Recreational systems, 1986). From the point of view of the scale of the space, the goal and the definition of criteria, the process of touristic division of the territory largely depends on the number, volume, configuration, name, specialisation, and boundaries of the allocated tourist areas (Kristev, 2019).

Natural-recreational resources are divided into 3 categories: physical, biological, and complex. Here, physical natural-recreational resources include geological, geomorphological, climatic, and hydrological resources; biological naturalrecreational resources include soil, vegetation, and wildlife; and complex natural-recreational resources include landscapes. These components form the basis of the formation of tourism and recreation systems and manifest themselves in a reciprocal form. For example, therapeutic mud belongs to both the geological and geomorphological groups, while mineral water belongs to both the geological and hydrological groups (Kruzhalin et al., 2014). Physical and biological natural-recreational resources are organically combined and inseparably integrated resources related to the flow of substances and energy.

In general, each type of natural-recreational resource is distinguished only based on their specific characteristics. They can be grouped according to their health characteristics, usability, evolutionary forms, and environmental criteria.

Summarising the above-mentioned components, it could be stated that tourism and recreation resources are a set of conditions that help to meet the needs of the population for tourism. Thus, in order to develop the tourism sector, first of all, the economic and geographical situation of the region is determined. The analysis takes into account the geographical location of the area, tourism and recreation services, the level of socio-economic development, the availability of infrastructure, hospitality, and other factors. The following are related to the comprehensive definition of tourism and recreation potential:

Natural potential includes natural monuments, their attractiveness, rate of use, protection, natural and artificial restoration, etc.

Historical-cultural potential includes a number of cultural-heritage tourism objects, their importance (international or local), degree of use, semantic value, etc.

The socio-economic potential is measured by the number of tourists visiting the area or facility but certain criteria are applied to the number of visitors. Thus, when the number of visitors to the region is too high, it can lead to the creation of ecologically tense zones. Socio-economic potential includes the current state of infrastructure, investments, tourism information centres, staff assistance, etc.

Taking into account the potential of tourism and recreation resources in zoning is one of the most important issues.

As it is known, physical-geographical zoning is based on the laws of nature, while economicgeographical zoning is carried out based on the laws of society, taking into account the rational use of nature (Hasanov, 2012). In the case of tourism and recreation zoning, the main focus is on identifying more attractive areas for tourists. This is determined by similar features of the area or by a combination of these features. Many scientists prefer natural and economic factors when zoning tourism. These indicators allow accurate reflection of the image of each region and revelation of its features. In addition, when conducting tourism-recreation zoning, it is necessary to take into account the potential tourismrecreation zones of the region, natural conditions, historical and cultural features, residential areas and density of the population, and features of hotels and recreation centres.

After determining the criteria for zoning, a digital map of the area is prepared, roads and road facilities are included in the GIS system, statistical materials on the number of settlements and population, demographic indicators are collected, systematised, and analysed.

The principle of classification and distribution of natural resources, the nature of climate comfort as a tourist resource, exoticism of landscapes, hydrology, natural monuments, the material and technical base of tourism, criteria for assessing financial, labour, and socio-economic resources should be analysed while conducting the tourism-recreation zoning in Gusar region.

\section{Critical review of work}

The territory of Gusar region, located in the northeast of the Republic of Azerbaijan, is 1.50 thousand $\mathrm{km}^{2}$, the population is 97.2 thousand people, and the population density is 65 people per $\mathrm{km}^{2}$. $21.1 \%$ of the population is settled in urban and $78.9 \%$ 
- in rural settlements. The distance between Gusar region and the capital Baku is $180 \mathrm{~km}$ (Regions of..., 2019). There are 88 rural settlements , 1 city (Gusar) and 1 settlement (Samur), in Gusar region. The length of the borders of Gusar region is $255 \mathrm{~km}$ and it borders Dagestan $(95 \mathrm{~km})$ of the Russian Federation in the north-west, Khachmaz region $(65 \mathrm{~km})$ in the north-east, Guba region $(70 \mathrm{~km})$ in the south-east, and Gabala region $(25 \mathrm{~km})$ in the south-west.

The climatic conditions of Gusar region provide wide opportunities for the development of the tourism sector here. Thus, before the trip, a tourist is primarily interested in the climate of the area, which, depending on the type of recreation he/she chooses, affects the efficient organisation of leisure time. (Imrani and Jafarova, 2020).

Due to the fact that the territory of Gusar region consists mainly of mountains, the vertical zonation of the climate is typical here. There are three climate types in the region. These include a moderately hot climate with evenly distributed precipitations, a moderately hot climate with dry summers, and a cold climate with dry winters. Due to the existence of a vertical zone in this area, the average temperature is $-5+2{ }^{\circ} \mathrm{C}$ in January, and $-17-22^{\circ} \mathrm{C}$ in summer. The average temperature in January is $1{ }^{\circ} \mathrm{C}$ in the plains, $-14^{\circ} \mathrm{C}$ in the high mountains, and $24^{\circ} \mathrm{C}$ and $2{ }^{\circ} \mathrm{C}$ in July, respectively. Annual precipitation is $350-1500 \mathrm{~mm}$. Precipitation falls mainly in the cold period of the year (Hajiyev and Rahimov, 1977). Exposure to the rains in the summer months, mainly in the second half of the day and in the evenings, does not cause any discomfort.

Low humidity in the summer months in Gusar region, the advantage of dry weather conditions, and abundance of oxygen are favourable for the organisation of climate resorts. Analysis of long-term meteorological forecasts shows that the recurrence of comfort levels in the summer months is $64 \%$ in the village of Urva, $60 \%$ in Khuray and Anig, $55 \%$ in Hazra and Ukur, and $62 \%$ in the foothills of Shahdag.

One of the important factors influencing the territorial organisation of tourism infrastructure in Gusar region is the relief. The south-western part of Gusar region is a mountainous area (north-eastern slope of the Main Caucasus Range, Yan Range), the central part is a sloping plain (Gusar sloping plain), and the north-eastern edge is the Samur-Davachi lowland. The south-western border of the region passes through the watershed of the Main Caucasus Range. The height of the area is $100 \mathrm{~m}$ in the lowland part and 4,466 $\mathrm{m}$ on Bazarduzu Mountain. The Salavat Pass $(2,895 \mathrm{~m})$ is also situated here. The Yan Range is partitioned by the valley of the Gusar River and divided into the Shahdag and Gizilgaya mountain massifs. There are several branches from the Shahdag in different directions, the longest of which is the Suval Range. Traces of ancient glaciers are clearly visible on the bare rocks in the highlands, parallel to the village of Laza in the Suval Range. Ancient glaciers stretch from the slope of the mountain to the bed of the Shahnabad River and are divided along the slope (Aliyev and Budagov 1973). These areas have favourable natural conditions for the development of mountain tourism. Along with this, Shahdag National Park was established $32 \mathrm{~km}$ away from Gusar region on December 8, 2006, where eco-tourism is also developed. The most interesting places for tourists in the national park are the constantly snowy peaks of the Main Caucasus Range - Bazarduzu (4,466 m), Shahdag (4,243 m), and Gizilgaya (3,739 m) (Abadov, $2,014)$. There are ecological tourism routes such as Laza-Waterfalls or icy waterfalls, Laza-mountain waterfalls, Laza-Sudur, Geleykhudat Heydar Aliyev peak, and Bazarduzu in the territory of the national park.

The soils in Gusar region are mainly grassy mountain-meadow, brown mountain-forest, typical and carbonate mountain-forest, and brown soils. The main vegetation of the mountainous area consists of broad-leaved forests on the sloping plains of alpine and subalpine meadows. Meadows and bushes also cover large areas in the region (Mammadov et al., 2012). Forests cover a large part of the territory $20 \%$ of Gusar region. The complex physical and geographical conditions of the area have led to uneven distribution, structure, kind, and age composition of forests (Mammadov and Asadov, 2010). The forests are dominated by hornbeam, oak, beech, poplar, and elm trees. Wild fruits are also widespread in the forests. The vegetation of the tea fields has wild fruits such as cornflower, cornel, cherry-plum, sumac, hawthorn, as well as natural medicinal plants such as dog-rose and blackberries.

In an area of 7 hectares, a beech forest called "Alistan Baba" near the village of Urva in the Gusar region is specially protected. The forest is rich in tall and old beech trees. In addition, a 200-year-old maple tree (Acer platanoides) in front of the Hazra village mosque and a 460 -year-old eastern plane tree (Platanus orientalis) in the old cemetery near the tomb of Sheikh Junayd attract tourists as a natural monument.

Gusar region is also distinguished by its rich fauna. There are wolves, bears, foxes, wild boars, mountain goats, rabbits, and other animals, as well as Caucasian grouse , Caucasian snowcock, chukar partridges, quails, wild pigeons, mallard ducks, and many other different types of birds in the region. 
Rivers are considered one of the most attractive areas for tourism development. The rivers of the northern region take their rise from the mountains of the Main Caucasus and flow into the Caspian Sea. (Gashqay and Mehdiyev 1950). Samur, Gusarchay, and Guruchay are the largest rivers in the region. Rivers and their waterfalls are of great interest to tourists.

The length of the Samur River is $216 \mathrm{~km}$. It originates in the highlands ( $3699 \mathrm{~m}$ ) between the Main Caucasus Range and the Samur Range watershed, which runs parallel to it in the north, and flows into the Caspian Sea. The Samur River crosses the border of Azerbaijan and Russia. The Samur-Davachi canal was built from the Samur River in 1940, and in the late 1950 s, the canal reached the Jeyranbatan reservoir.

The length of the Gusarchay is $108 \mathrm{~km}$, which takes its rise from Bazarduzu Mountain $(3780 \mathrm{~m})$ and flows into the Caspian Sea. The main tributaries are the Shahnabat (12 km long) and Sikhur (14 km long) rivers. The water of Gusarchay is widely used for irrigation of agricultural lands; part of the water is discharged into the Samur-Absheron water canal. Gusar, Khuray, Anik, and Guzun Hydroelectric Power Stations have been built on the river (Museyibov, 1998). The length of the Guruchay is $77 \mathrm{~km}$; it takes its rise from the Yan ridge $(2550 \mathrm{~m})$ of the Main Caucasus and flows into the Caspian Sea. River water is widely used to irrigate agricultural fields.

Along with the economic importance of the above-mentioned rivers, they also have great tourism potential. There are recreation centres and picnic sites around the rivers. At the same time, there are many waterfalls on the rivers flowing through the territory of Gusar region. For this reason, Gusar region is called the land of waterfalls. Laza $(54 \mathrm{~m})$ and Shahnabal (32 m) waterfalls, as well as Suvar and Kuzun (28 m) waterfalls, which are among the most beautiful natural landscapes in the territory of Azerbaijan, are located here. These waterfalls attract tourists with their grandeur, abundance of water, and mysterious scenery.

Laza and Shahnabat waterfalls are located on the Gurgur River, the right tributary of the Gusar River, near the village of Laza, at an altitude of 2,200 m above sea level. As Laza and Shahnabat waterfalls freeze in winter, ice-climbing competitions are held here. Suvar waterfall is also located near the village of Laza, at an altitude of 2,000 m above sea level. Kuzun waterfall is situated at an altitude of $1,800 \mathrm{~m}$ near Kuzun village.

The territory of Gusar region is rich in sources of mineral and thermal waters. There are about 20 springs here, the total flow rate of which is $0.2 \mathrm{~m}^{3}$.
Sources of table mineral water, usually cold, are most common in the Shahdag and Sudur directions. A high flow rate of water is characteristic of such mineral springs as Cherkebulag, Shahbulag, and Kuzunbulag. Currently, these waters are not used for economic and tourist purposes.

There are many archaeological monuments in Gusar region. They include the mound of the 1st millennium B.C. in Khazra village; Galakhur settlement of the 4th-16th centuries; Mahmudtepe settlement of the 1st millennium B.C., $2 \mathrm{~km}$ northwest of Gadazeykhur village; the medieval settlement of Gadazeykhur village; the Bronze Age Gaflatepe settlement, $1 \mathrm{~km}$ south of Gadazeykhur village; the Bronze Age Govdishan hill mounds , $2 \mathrm{~km}$ east of Imamgulu village; Gunutepe settlement of the 3rd-7th centuries in Gunduzgala village; Maysertepa town of 1th-3rd centuries, $500 \mathrm{~m}$ north-west of Badirgala village; the medieval Kalaysuvar settlement in Samur settlement; a necropolis of the 4th-7th centuries on the left bank of the Gusar River, near Anig village; Kukhur hills settlement of 4th-7th centuries, $1.5 \mathrm{~km}$ north of Kukhuroba village; Iron Age mound, 50-60 $\mathrm{m}$, on the left side of the Baku-Derbent highway near the Kukhuroba village; Iron Age necropolis in Hil village, etc. (Approved by..., 2001).

The territory of Gusar region is rich in historical and architectural monuments. These include the ruins of 13th-century castle walls in the village of Anig and a 19th-century mosque; the tomb and mosque of Sheikh Junayd in Hazra village built in 1544; a medieval caravanserai in Kirig village; a medieval mosque in Balagusar village; a mosque in Hil village (19th century); Khudat fortress of the 17th century near the Kohna Khudat village; a mosque of the 18th century; mosques in the villages of Khuray, Boyuk Murug, and Tagaroba; mosques of the 19th century in the villages of Zindanmurug, Jagar, Gunduzgala, Chetkun, Mujug, etc..

Along with the historical and architectural monuments found in Gusar region, folk art such as carpet weaving, woodcarving, weaving socks and gloves from colourful coarse wool, processing of sheepskins, etc. has maintained its importance to this day.

One of the important conditions for the development of tourism in Gusar region is the availability of hotel complexes in accordance with international standards. Although the natural and historical-cultural tourism potential of the region is attractive for tourists, it will not be possible to develop the tourism sector at any level without modern hotel complexes. Unlike other areas of the tourism sector, hotels have a wide range of organisational structures, 
which has a significant impact on economic performance.

There were 17 hotels for tourists to spend the night in Gusar region in 2018, most of which were concentrated in Gusar city. The number of rooms in hotels is 981 and the one-time capacity is 2,253 people. The number of hotels, the number of rooms and full hotel capacity have increased over the past five years. If we compare these indicators for 20172018, it could be observed that there has been a decrease. However, the increasing trend in the number of overnight stays in hotels was observed every year, and in 2018, the number of overnight stays was 107,496 people (Table 1). skiing. However, at the beginning of winter, the lack of natural snow cover in the complex and the relative humidity of $80 \%$ require the provision of mountain ski slopes with artificial snow-making (generation) systems which requires additional funds. There are currently five hotels in the Shahdag tourist complex: Shahdag Hotel and Spa (for 346 people), Zirve Hotel (for 86 people), Gaya Residences (for 62 people), Peak Palace (for 334 people), and Park Chalet (for 328 people). The complex can accommodate 5,000 tourists at a time.

Along with large hotels, there are more than 50 small motels, hostels, and recreation centres in Gusar region. They include Chateau Hotel Gusar, Alpine

Table 1. Main indicators of hotels in Gusar region

\begin{tabular}{|l|c|c|c|c|c|}
\hline & 2014 & 2015 & 2016 & 2017 & 2018 \\
\hline Number of hotels, unit & 14 & 17 & 16 & 19 & 17 \\
\hline Number of rooms in hotels, units & 434 & 770 & 910 & 984 & 981 \\
\hline Full capacity of hotels, people & 961 & 1625 & 1721 & 2352 & 2253 \\
\hline Number of overnight stays in hotels, person-night & 28,452 & 37,625 & 70,495 & 101,581 & 107,496 \\
\hline - number of citizens of the country & 25,341 & 32,067 & 50,223 & 65,040 & 41,163 \\
\hline - number of foreign citizens & 3,111 & 5,558 & 20,272 & 36,541 & 66,333 \\
\hline
\end{tabular}

Source: Tourism in Azerbaijan. Baku, 2019

During the years studied, the income of hotels in Gusar region increased by 10.3 times and expenses by 7.2 times. However, in 2015 and 2017, hotel revenues and expenditures were lower than in other years. The most sorrowful thing is that the difference between income and expenses was negative in all years except 2017. The largest difference (USD -55,510,824) was recorded in 2018 (Figure 2).

There is "Shahdag" winter-summer tourism complex in the territory of Gusar region, at an altitude of 1,440-1,640 $\mathrm{m}$ above sea level. The complex is equipped with a ropeway and ski trails, bench-type lifting facilities, and infrastructure for mountain
Inn Gusar, Gayi Bulakh Resort Center, Star Gusar Resort Center, North Motel, Shah Bulag, and others (Figure 2). However, they do not fully meet the needs of tourists visiting the region.

As a result of the research, it was determined that the average occupancy rate of hotels varies between $60-80 \%$ in summer and $30-40 \%$ in winter. The average stay of tourists in hotels is 1-3 days, and the average price of a room is USD 35-70.

The zoning of tourism and recreation resources of Gusar region was based on both natural and socioeconomic resources. The territory of the region is divided into three zones in terms of tourism and

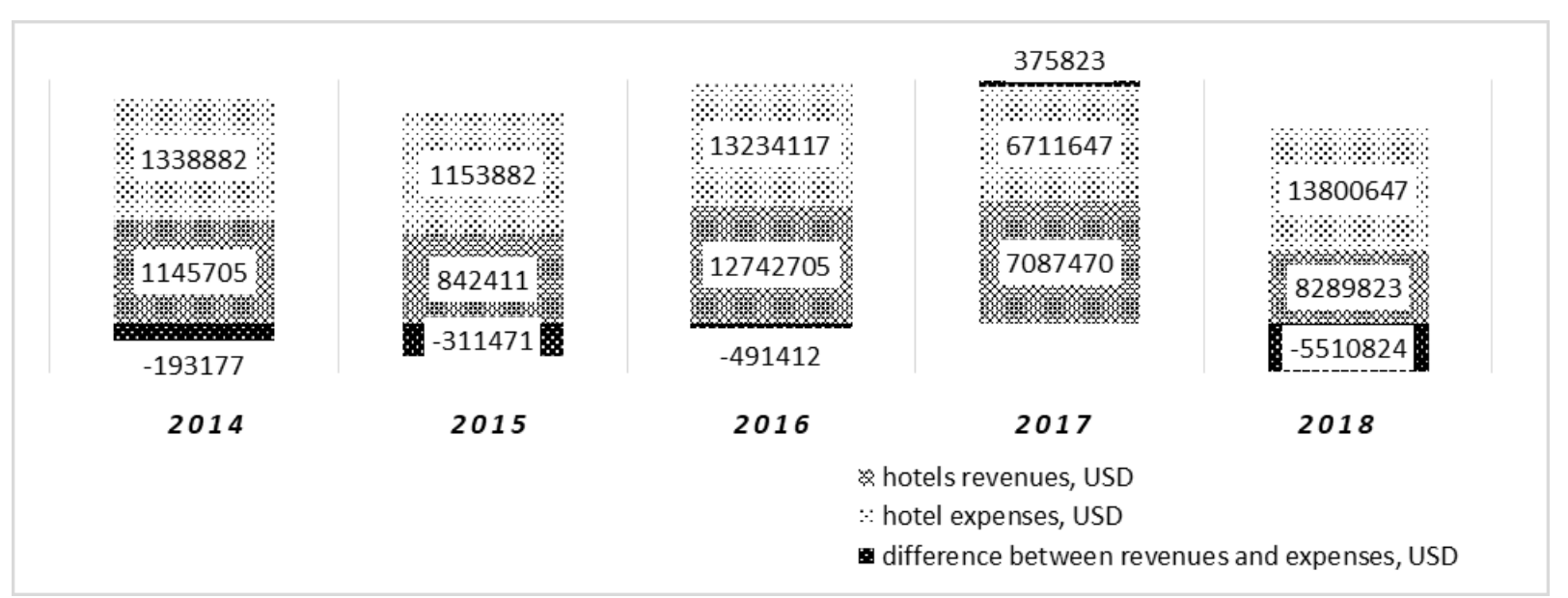

Fig. 1. Revenue and expenses of hotels and difference between them in Gusar region

Source: Tourism in Azerbaijan. Baku, 2019 


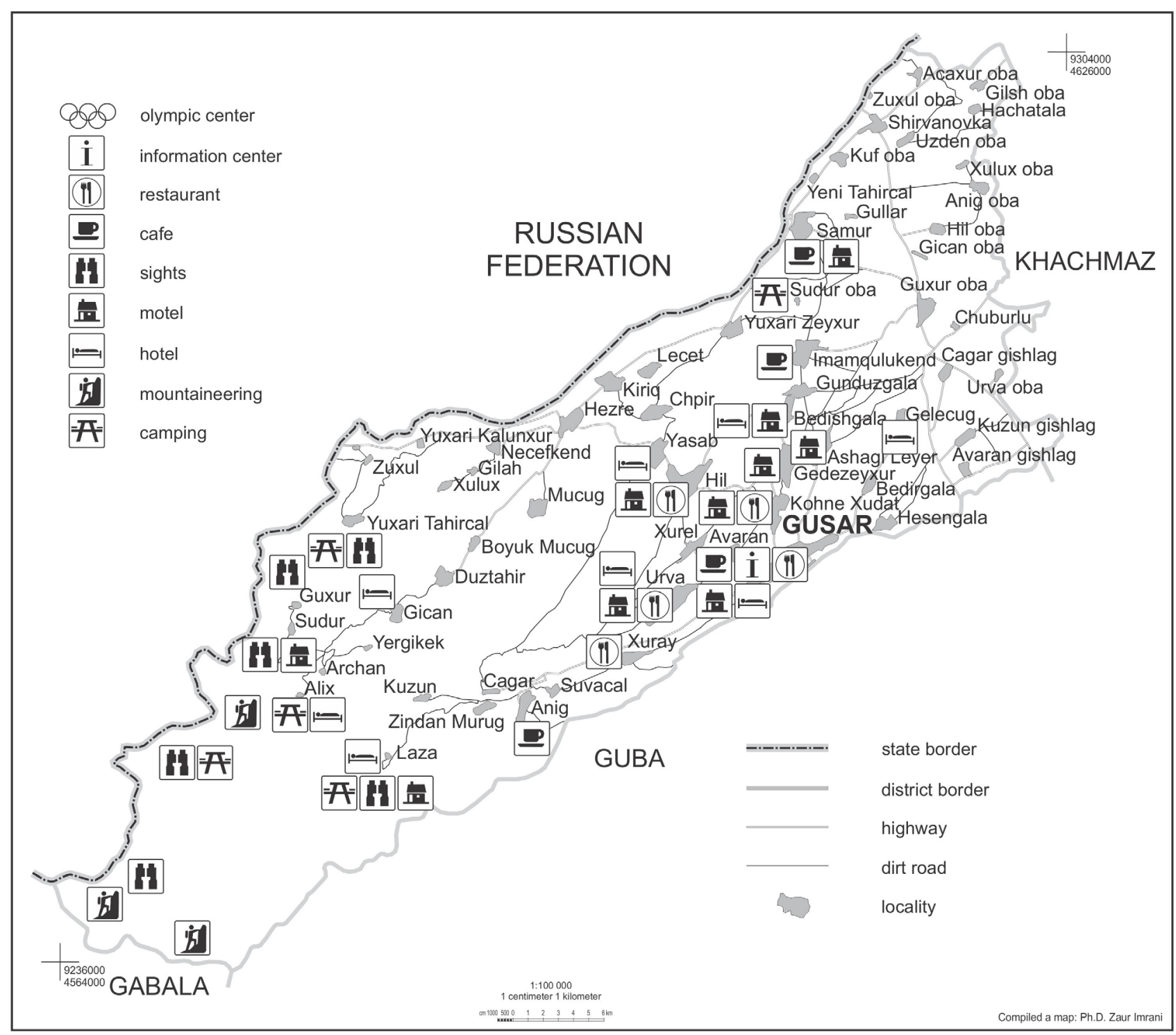

Fig. 2. Zoning map of tourism and recreation resources of Gusar region

recreation resources. The first zone includes areas that are more developed than other areas in terms of the pace of development of the tourism sector; the second zone includes areas that are attractive and moderately developed in terms of ecotourism; and the third zone includes areas that are relatively underdeveloped despite their potential.

Tourism potential and forms of entrepreneurship develop faster as a result of effective activities. As a leading factor in tourism activities, small and medium enterprises should be expanded as a more efficient way. In particular, the use of small business products for consumption in the field of tourism can increase its potential and turnover by expanding the market of tourism services (Mammadov, 2013).

Tourism service is a labour-intensive field and opens wide prospects for the development of small and medium entrepreneurship. The income obtained in a short period is of interest to the entrepreneur. The development of tourism is of great importance in creating new jobs, reducing unemployment, preventing migration flows, and developing new housing. Some jobs in tourism enterprises are seasonal and in some cases require the use of more female labour (housekeeping, laundry, kitchen worker, etc.). This allows local residents to earn extra income, thereby improving the social situation of the family.

Labour resources are the main productive forces of society. The number, dynamics, and professional and educational level of these resources are the most important factor in the development of the economy in different regions of the country. The level of labour supply affects the formation and territorial organisation of the economy and allows the development of labour-intensive industries (Abbasov, 1998). Thus, the level of development of productive forces is related to the formation of life, spiritual and household traditions, the diversity of geographical conditions, and the possibility of its use. 
At present, there are local tourist routes in Gusar region. However, although these routes mainly reflect historical, cultural and natural monuments, they are of local importance and can play an exceptional role in the employment of the population living in the region at any level. In addition to guiding activities, the locals help to meet the daily food needs of tourists and receive them at home as guests.

By conducting the $\boldsymbol{S W O T}$ analysis, it is possible to identify its strengths and weaknesses, taking into account the positive and negative effects of the tourism sector. The analysis also identifies potential threats to the tourism sector and relevant opportunities for its development (Loudon et al., 2005). The advantage of SWOT analysis is that the strengths are further developed, appropriate measures are taken to eliminate the weaknesses, ways to address the threats to sustainable development are sought, a tourism strategy is developed, and maximum efforts are made to take advantage of local opportunities. In this case, there is a need to analyse the current state of tourism and recreation resources in Gusar region and their use by conducting the SWOT analysis.

It should be noted that as a result of the SWOT analysis, various options for linking the environment, competitive conditions, internal resources, and experience gained are developed, and specific tasks of marketing activities of the business unit are identified (Mammadov, 2007). Thus, their application is highlighted by identifying optimal ways to develop the tourism sector.

When conducting the SWOT analysis for Gusar region, the current state of hotels, along with more attractive natural and historical-architectural monuments, have also been studied. In this case, the main goal was to determine the dynamics of the development of the tourism sector (Table 2).

The results of the SWOT analysis show that despite the risks in Gusar region, there are favourable conditions for a high level of development of the tourism sector. To this end, the scientific basis and information provision of tourism development

Table 2. SWOT analysis of tourism-recreation resources and their use in Gusar region

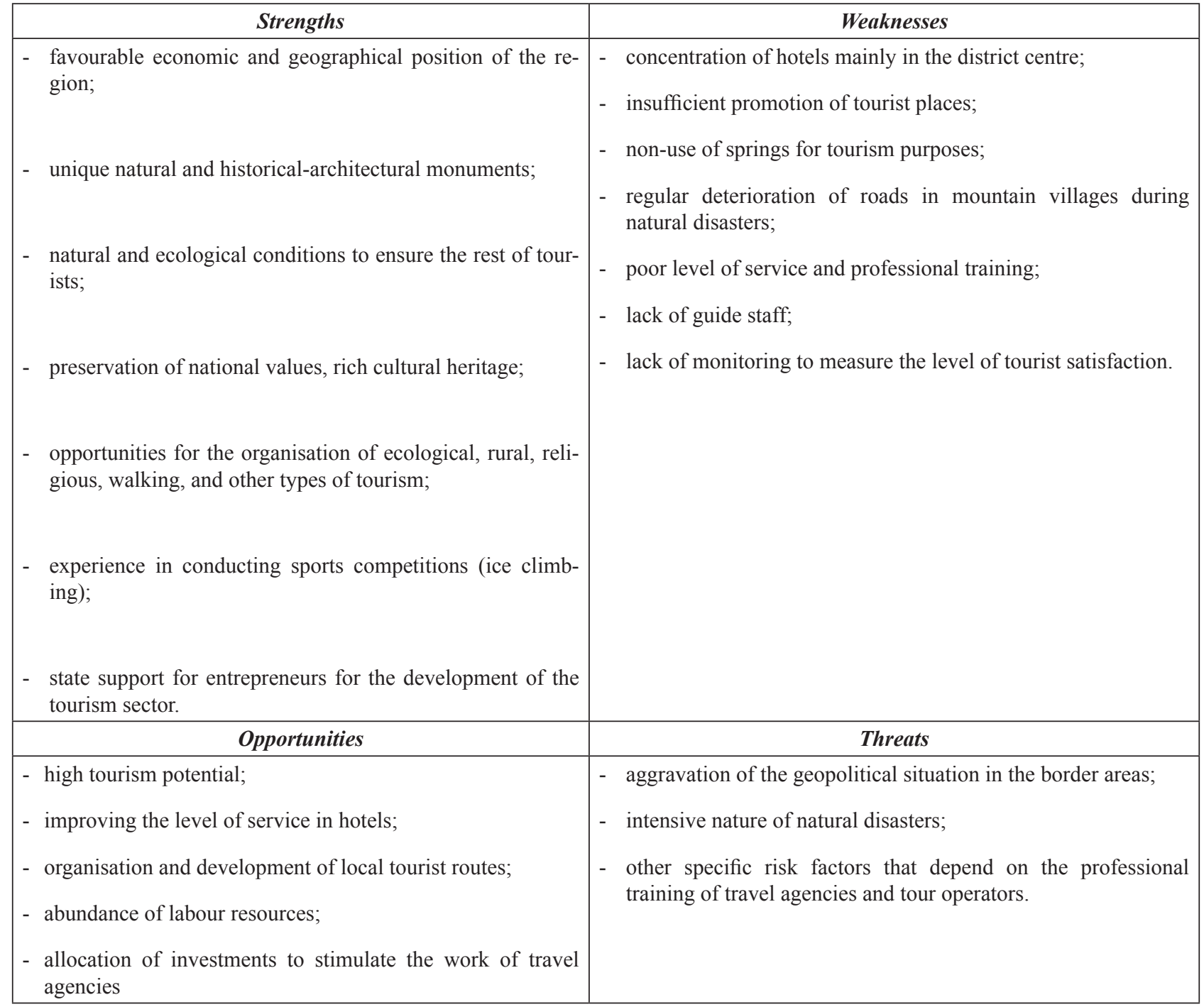


strategy should be strengthened, foreign and local investors should be attracted to the region, the number of hostels and guesthouses should be increased, their service should be improved, and the tourism infrastructure should be mobilised, using the existing potential fully and effectively. Thus, the growing attention to the tourism industry will also play a supporting role in solving the employment problem.

\section{Results}

Assessment of tourism and recreation resources, their integrated use from an economic and environmental point of view affect the formation and development of the modern tourism market. Taking into account the natural conditions and economic potential of Gusar region, the zoning of tourism and recreation resources was carried out and the following results were obtained:

- Climatic conditions and relief factors of Gusar region, as well as the fact that a part of Shahdag National Park is in the territory of the region open wide opportunities for the development of the tourism sector. At present, ecological tourism routes operate in the National Park. At the same time, numerous waterfalls, springs around villages, as well as archaeological and historical-architectural monuments on large rivers such as Samur, Gusarchay, and Guruchay, and their tributaries prove the high tourism potential of the region.

- Although the performance of hotels in Gusar (number of rooms, full hotel capacity, and number of overnight stays) is high, the difference between the income and expenses of hotels has been negative in all years except 2017. As this indicator has a negative impact on the development of the tourism sector, it has weakened the service sector. To solve the problem, small motels, hostels, and recreation centres have been established in the region, and state support is provided to local entrepreneurs.

- Zoning of tourism and recreation resources of Gusar region was carried out, and according to the pace of development, the region's territory has been divided into three zones: highly, moderately, and relatively poorly developed zones. The first zone includes Gusar city, surrounding areas and "Shahdag" winter-summer tourism complex; the second zone includes forests, rivers, waterfalls, springs, etc., which are more attractive in terms of the development of ecological tourism; and the third zone includes areas with high tourism potential, but poorly developed.

- SWOT analysis of the tourism sector in Gusar region determined that the area had sufficient potential for high-level development of the tourism sector. Effective use of these opportunities would allow Gusar region to become one of the most popular tourist areas in Azerbaijan in the future.

\section{References}

Abbasov, J.R., 1998. Economic and social geography of the Republic of Azerbaijan. Baku: BSU, 124.

Abadov, M.K., 2014. Tourism in Azerbaijan and its development problems. Baku: Sharg-Garb, 248.

Alexandrova, A.Yu., 2002. Mejdunarodniy turizm [International tourism]. Moskva: Aspekt Press, 338 (in Russian).

Aliyev, H.A., Budagov, B.A., 1973. Legendary Mountains. Baku: Elm, 86.

Approved by the Resolution of the Cabinet of Ministers of the Republic of Azerbaijan dated August 2, 2001. 132. Baku: 162.

Fedotov, V.I., 2013. Turistsko-rekreasiionnie zoni i rayoni [Tourist and recreational zones and areas]. Ekologo-geograficheskiy atlas. Voronezh: Izd-vo. Voronezhskiy gosudarstvenniy universitet, 417-419 (in Russian).

Gashqay, M.A., Mehdiyev, Sh.F., 1950. Natural resources of the republic. Baku: Ushaqganjnashr, 68.

Hajiyev, G.A., Rahimovm, V.A., 1977. Climatic characteristics of the administrative regions of the Azerbaijan SSR. Baku: Elm, 270.

Hasanovm, T.G., 2012. Economic-geographical zoning. Baku: Baku University, 245.

Imranim, Z.T., Jafarovam, N.R., 2020. The role of the tourism in the socio-economic development of mountain rural areas of Azerbaijan (represented by Guba and Gusar administrative regions). Geography and natural resources, 1 (11), 64-69.

Imrani, Z.T., 2018. Potential opportunities and zoning of tourism and recreation resources of the Northern region of Azerbaijan. Republican scientific-practical conference on "Prospects for the establishment of tourism and recreation zones in the Republic of Azerbaijan". 8-13.

Kristev, V.K., 2019. Turistskoe rayonirovanie: diskurs o metode [Tourist zoning: discourse on the method]. Vestnik Moskovskogo Universiteta, seriya Geografiya, 5. 50-59 (in Russian).

Kruzhalin, V.I., Mironenko, N.S., Siegern-Korn, N.V., Shabalina N.V., 2014. Geografiya turizma [Geography of tourism]. Moskva: Izd-vo. Federalnoe agenstvo po turizmu, 336 (in Russian).

Loudon, D., Stevens, R., Wrenn, B., 2005. Marketing management. New York: Howorth, 370.

Mammadov, A.T., 2007. Basics of marketing. Baku: University of Economics, 336.

Mammadov, E.G., 2013. Regional features of the formation and management of the tourism market in Azerbaijan. Baku: Ganjlik, 172.

Mammadov, G.Sh., Asadov, K.S., 2010. Forest ecology. Baku: Elm, 452. 
Mammadov, G., Yusifov, E., Khalilov, M., Karimov, V., 2012. Ecotourism potential in Azerbaijan, in 2 volumes, I. Baku: Sharg-Garb, 360.

Museyibov, M.A., 1998. Physical geography of Azerbaijan. Baku: Maarif, 400.

National Accounts of Azerbaijan, 2019. Baku: DSK, 138.

Rekreasiionnie sistemi, 1986. [Recreational systems]. Pod redaksii N. Mironenko, M. Bochvarova. Moskva:
Izd-vo. Moskovskiy gosudarstvenniy universitet, 136. (in Russian)

Regions of Azerbaijan, 2019. Baku: SSCAR.

Strategic Roadmap for the development of the specialised tourism industry in the Republic of Azerbaijan, 2016. Decree of the President of the Republic of Azerbaijan dated December 6, 2016. Baku. 